\title{
Vegetation Burning in Pampa Biome Altered the Chemical Composition of Rainfall
}

\author{
Grasiele Dick $^{1}$ (D), Mauro Valdir Schumacher ${ }^{1}$ \\ ${ }^{1}$ Universidade Federal de Santa Maria - UFSM, Santa Maria/RS, Brasil
}

\begin{abstract}
Rainfall is one of the primary nutrient inputs to vegetation and its chemical composition is dependent on air quality as falling rain scavenges gaseous and particulate emissions from natural, industrial, and agricultural activities. The objective of this study was to evaluate whether the vegetation burn in a region of the Pampa biome influences the $\mathrm{pH}$ and chemical composition (anions) in incident rainfall. Nitrate, sulfate, and chloride concentrations, as well as the $\mathrm{pH}$ of the rainwater, were influenced by suspended particles in the atmosphere from biomass burning of native grassland and pasture renewal. The rainwater was acidified by, ash, and soot, which introduced large amounts of chloride and sulfate into the ecosystems caused by burning vegetation.
\end{abstract}

Keywords: rainwater acidification, anions, atmospheric pollution. 


\section{INTRODUCTION}

Rainwater contains cations and anions that enter the atmosphere as dust (Wu et al., 2013), marine spray, suspended soot from vegetation burning (Laclau et al., 2003), volcanic dust (Vet et al., 2014), industrial emissions, and outputs from other natural and anthropogenic sources (Shen et al., 2013). These sources introduce a multitude of ion species to the atmosphere, including calcium, potassium, sulfate, and nitrogen oxides, which affect the chemical nature of rainwater (Vet et al., 2014). The degree of atmospheric impact on the chemical composition of incident rainfall varies according to a region's geography and will change through time and in response to fluctuations in the volume and intensity of rainfall (Laclau et al., 2003).

The chemical composition of rainwater can be a direct indicator of the natural and agricultural practices in the area, particularly of vegetation burning and air pollutant emissions (Laclau et al., 2003). The effects of increasingly acidic rainwater, such as corrosion of buildings and monuments, loss of soil productivity, mortality of fauna and flora, are already recurrent in developed countries (Duan et al., 2016; Wu et al., 2013).

Particles and gaseous compounds released into the atmosphere directly influence the $\mathrm{pH}$ and ion concentrations of rainwater, which interacts with vegetation through plant surfaces and soil (Eisalou et al., 2013; Robertson et al., 2000). When rainwater reaches the soil, the chemicals it carries can contribute to the available mineral nutrients or adversely affect the development of vegetation and agricultural crops (Wamelink et al., 2009). Due to the relevant contribution of rainfall to nutrient input in the soil, fertilization management strategies for most crops can be adopted based on studies that evaluate the chemical composition of the rainwater. Fertilizer recommendations can be optimized, thus avoiding unnecessary nutrient expenditure and achieving cost savings.

Studies of the chemical composition of rainwater are revealing the significant effects of pollutants, such as sulfates, nitrates, and chlorine-containing molecules, on the acidification of rainfall and consequential damage to varied types of vegetation (Duan et al., 2016). The objective of this study was to evaluate whether the vegetation burning influences the $\mathrm{pH}$ and chemical composition (anions) of incident rainfall in a region of the Pampa biome, Rio Grande do Sul state, Brazil.

\section{MATERIAL AND METHODS}

This study was carried out in native grassland, surrounded by pasture, silviculture and agriculture areas in São Gabriel municipality, region of the Pampa biome, Rio Grande do Sul state, Brazil (geographic coordinates $54^{\circ} 10^{\prime} 0.8^{\prime \prime} \mathrm{W}$; $30^{\circ} 30^{\prime} 12^{\prime \prime} \mathrm{S}$ ). The native grassland of the region is a vegetation typology with a wide diversity of low grasses and shrubs, interspersed with forest canopies along the watercourses (Ferreira \& Setubal, 2009). In September the practice of intentionally burning for vegetation management is very common in the native grassland and pastures areas of the Pampa biome, that are used for cattle grazing as it is an alternative for pasture renewal and elimination of invasive plants. In September the number of burning focus increased in Brazil (Mélo et al., 2011).

The Köppen climate classification of the region is Cfa, humid subtropical type with hot summers and without dry season. The average monthly temperature of the hottest month is above $22^{\circ} \mathrm{C}$ and in the coldest month the monthly average ranges between $-3{ }^{\circ} \mathrm{C}$ to $18^{\circ} \mathrm{C}$. In terms of rainfall, the minimum during the driest month is still greater than $40 \mathrm{~mm}$ and the average annual precipitation can range from 1,600 to $1,900 \mathrm{~mm}$ per year (Alvares et al., 2014). The historical averages, obtained over 30 years of observation (Figure 1), indicate that the lowest temperatures occur in the months of June, July, and August (winter season) and

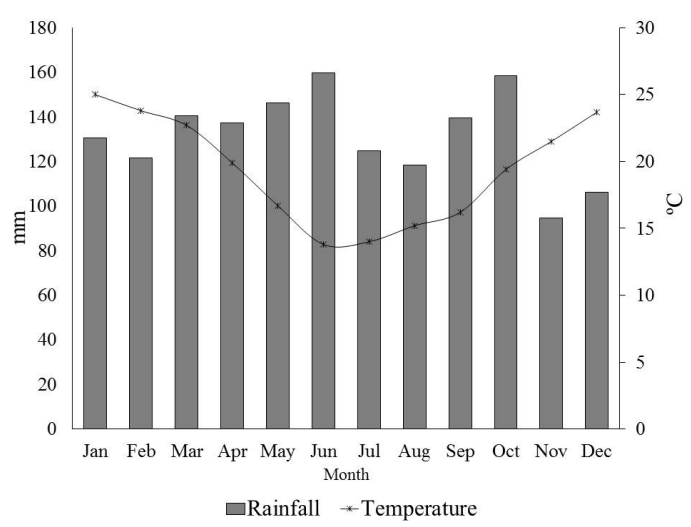

Figure 1. Climate diagram of São Gabriel municipality, Rio Grande do Sul state, Brazil. Source: INMET (2018). 
the highest temperatures occur throughout November to February (summer period). Precipitation is well distributed throughout the year; however, there is less rainfall during the hottest months (INMET, 2018).

The volume of incident rainfall was measured using three fixed collectors and for the chemical analysis of the rainwater, collected from February to November 2015, three collectors were installed (Figure 2).

The incident rainfall was collected biweekly, with subsequent aseptic treatment of all collectors. The volume of rainfall in the fixed collectors was quantified on site by means of a graduated ruler and aliquots from the smaller collectors were stored in sterile plastic jars and sent to the laboratory for chemical analysis. From these aliquots, the $\mathrm{pH}$ was measured using a $\mathrm{pH}$ meter with a glass electrode (Metrohm $827 \mathrm{pH}$ lab) following filtration through a $0.45 \mu \mathrm{m}$ pore filter. Aliquots were also analyzed by ion chromatography in order to determine the concentrations of $\mathrm{NO}_{3}^{-}$(nitrate), $\mathrm{SO}_{4}{ }_{4}^{2-}$ (sulfate), and $\mathrm{Cl}^{-}$(chloride) ions (APHA, 1998). Rainfall volumes in milliliters were determined for each biweekly collection following and, the amount of each anion type scavenged by the rainfall was determined from the product of the anion concentration and the volume of precipitation.

The logarithmic transformation of the concentration data for each anion followed a normal distribution and homogeneity of variances, which were verified by the Shapiro-Wilk and Bartlett tests, respectively. The Scott-Knott's test was used to determine during which months the mean concentrations of the three

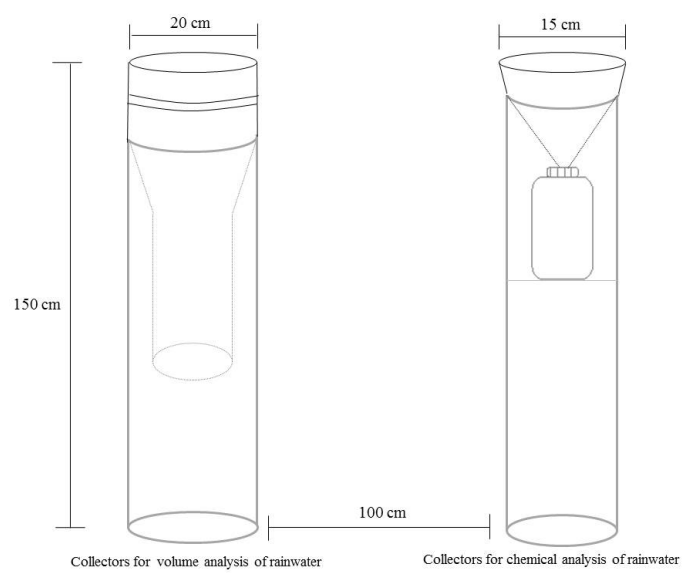

Figure 2. Rainfall collectors for volume and chemical analysis. anions were significantly different. The test was applied in a completely randomized design with different numbers of repetitions and the significance level set to 5\%.

\section{RESULTS AND DISCUSSION}

The total volume of incident rainfall during 2015 was $1,782.3 \mathrm{~mm}$. Rainfall varied throughout the year, with the minimum amount of precipitation recorded in February and the maximum in October and December (Figure 3).

The amount of rainfall in 2015 was within the average expected for the region; however, above-average precipitation was observed from 2011 to 2014 (INMET, 2018). High precipitation volumes throughout in Rio Grande do Sul state were recorded in 2015 under the influence of the El Niño climate phenomenon, which intensified the hydrological cycle, especially in the summer season (Mélo et al., 2011). In Brazil, El Niño is characterized by prolonged drought in the semi-arid northern regions and intensified rainfall in the humid southern region. These changes to the hydrological cycle are caused by the increased Pacific temperature altering the circulation of the Atlantic Ocean, which interferes with the rainfall indexes and temperatures of regions around the planet (Costa, 2012).

The $\mathrm{pH}$ of the rainwater varied throughout the year, ranging from 4.6 (September) to 6.4 (April) (Figure 4). These differences in $\mathrm{pH}$ are related to the cations and anions in the rainwater as the lowest $\mathrm{pH}$ values were recorded in the months when there were higher concentrations of $\mathrm{Cl}^{-}$and $\mathrm{SO}_{4}{ }^{2-}$. High concentrations

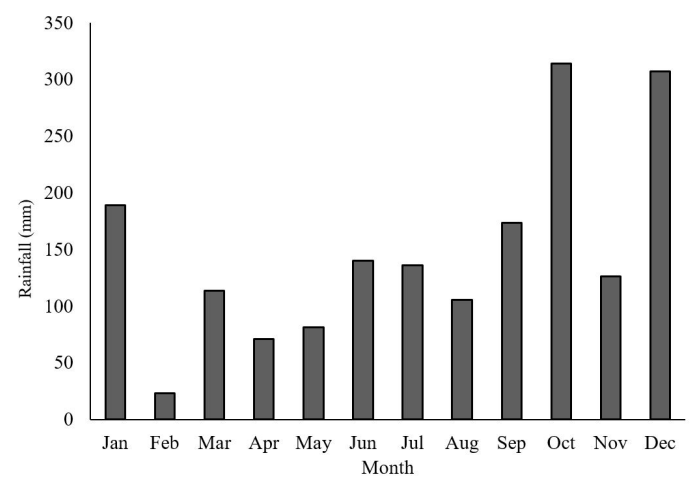

Figure 3. Monthly volumes of incident rainfall during the year 2015 in an area inside São Gabriel municipality, Pampa biome. 


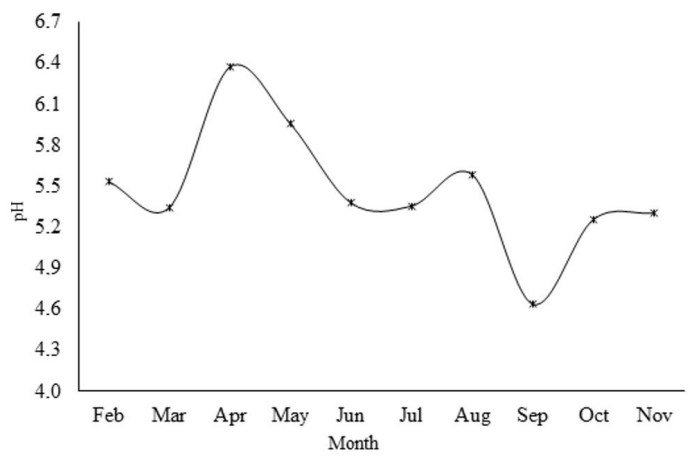

Figure 4. $\mathrm{pH}$ values in incident rainfall in an area inside São Gabriel municipality, Pampa biome.

of $\mathrm{SO}_{4}{ }^{2-}$ in rainwater indicate acid rain, which is a serious ecological problem exacerbated by emissions of this sulfur dioxide and other sulfur-containing pollutants (Duan et al., 2016). The uptake of $\mathrm{NO}_{3}^{-}$into the atmosphere may also contribute to increased $\mathrm{pH}$ by releasing $\mathrm{OH}^{-}$or $\mathrm{COO}^{-}$into rainfall (Laclau et al., 2003).

The rainwater acidification in September may be a reflection of the increased vegetation burning. The practice of intentionally burning for vegetation management is very common in areas of the Pampa biome that are used for cattle grazing as it is an alternative for pasture renewal and elimination of invasive plants. The use of fire to manage vegetation directly affects the $\mathrm{pH}$ and chemical composition of rainwater as sulfate, nitrite, nitrate, chlorine, potassium, calcium, phosphorus, and other ions, are released from biomass and emitted into the atmosphere through burning (Laclau et al., 2003).

Burning ashes, which are rich in minerals, oxides, and other compounds, lead to acidification and increased concentrations of $\mathrm{Cl}^{-}$and $\mathrm{SO}_{4}{ }^{2-}$ in the precipitation water (Armbruster et al., 2003). The increased atmospheric particle loading explains the differences between the levels of anions in the rainwater over the months, especially for $\mathrm{Cl}^{-}$and $\mathrm{SO}_{4}{ }^{2-}$ (Table 1 ).

Atmospheric particles composed of dust (Wu et al., 2013), soot released after vegetation burning (Laclau et al., 2003), volatilized nutrients from fertilization with limestone powder (Calil et al., 2010), and residues from liming in rural areas, are some of the sources of anions and cations to the atmosphere, which can affect the $\mathrm{pH}$ of rainwater and also increase the concentrations of $\mathrm{NO}_{3}^{-}, \mathrm{SO}_{4}^{2-}$ and $\mathrm{Cl}^{-}$. When these ions are present in rainwater they contribute to the nutrition of agricultural crops, native grasslands, pastures, and
Table 1. Anions concentrations (mean \pm standard deviation) in incident rainfall in an area inside São Gabriel municipality, Pampa biome.

\begin{tabular}{cccc}
\multirow{2}{*}{ Month } & $\mathbf{C l}^{-}$ & $\mathbf{N O}_{3}{ }^{-}$ & SO $_{4}{ }^{2-}$ \\
\cline { 2 - 4 } & \multicolumn{3}{c}{$\mathbf{m g ~ L}^{-1}$} \\
\hline Feb & $0.79 \pm 0.05 \mathrm{~b}^{*}$ & $0.45 \pm 0.32 \mathrm{a}$ & $0.33 \pm 0.05 \mathrm{~b}$ \\
\hline Mar & $0.60 \pm 0.18 \mathrm{~b}$ & $0.22 \pm 0.02 \mathrm{~b}$ & $0.27 \pm 0.08 \mathrm{~b}$ \\
\hline Apr & $1.02 \pm 0.45 \mathrm{~b}$ & $0.22 \pm 0.00 \mathrm{~b}$ & $0.70 \pm 0.23 \mathrm{~b}$ \\
\hline May & $1.83 \pm 1.56 \mathrm{~b}$ & $0.08 \pm 0.03 \mathrm{~b}$ & $0.78 \pm 0.43 \mathrm{~b}$ \\
\hline Jun & $0.32 \pm 0.13 \mathrm{~b}$ & $0.10 \pm 0.02 \mathrm{~b}$ & $0.53 \pm 0.11 \mathrm{~b}$ \\
\hline Jul & $0.31 \pm 0.01 \mathrm{~b}$ & $0.13 \pm 0.02 \mathrm{~b}$ & $0.29 \pm 0.01 \mathrm{~b}$ \\
\hline Aug & $0.42 \pm 0.01 \mathrm{~b}$ & $0.14 \pm 0.06 \mathrm{~b}$ & $0.71 \pm 0.02 \mathrm{~b}$ \\
\hline Sep & $2.48 \pm 0.23 \mathrm{a}$ & $0.21 \pm 0.07 \mathrm{~b}$ & $1.58 \pm 0.67 \mathrm{a}$ \\
\hline Oct & $0.36 \pm 0.21 \mathrm{~b}$ & $0.24 \pm 0.16 \mathrm{~b}$ & $0.75 \pm 0.34 \mathrm{~b}$ \\
\hline Nov & $0.38 \pm 0.10 \mathrm{~b}$ & $0.14 \pm 0.05 \mathrm{~b}$ & $0.40 \pm 0.00 \mathrm{~b}$ \\
\hline
\end{tabular}

*Values followed by the same letter in the row, do not differ statistically by Scott-Knott's test, at 5\% error probability level.

silviculture, which are widely cultivated in the Pampa biome. It is important to emphasize that deposition of particulates on vegetation is carried out after the interception of water by the leaves, which leaches metabolites and increases the amount of the nutrients that reach the soil, modifying its fertility (Shen et al., 2013; Heartsill-Scalley et al., 2007).

Increased concentrations of $\mathrm{SO}_{4}^{2-}$ and $\mathrm{Cl}^{-}$, in detriment of other ions, were observed in the rainfall of the Pampa biome (Dick et al., 2018) and this has also been observed in studies from Puerto Rico (Heartsill-Scalley et al., 2007), and Congo (Laclau et al., 2003). Laclau et al. (2003) identified that the predominance of $\mathrm{SO}_{4}^{2-}$ and $\mathrm{Cl}^{-}$in rainwater in rural areas of Congo is dependent on the location of the study site as their study was set up $10 \mathrm{~km}$ from the sea and under strong influence of marine spray.

Due to the increased water volumes and anion concentrations, rainwater in the region contained high amounts of anions, especially $\mathrm{Cl}^{-}$and $\mathrm{SO}_{4}^{2-}$ (Table 2).

In the present study, there were higher amounts of $\mathrm{Cl}^{-}$and $\mathrm{SO}_{4}{ }^{2-}$ in rainfall compared to the studies by Heartsill-Scalley et al. (2007) in Puerto Rico, Dick et al. (2018) in Brazil (Pampa biome), and Ashagrie \& Zech (2010) in Ethiopia. The dissolved ions in rainwater will be incorporated into the soil and excess nitrate (Wamelink et al., 2009), chloride, and sulfate may impair the development of vegetation (soybean, corn, pasture, trees, among other types of soil cover) by causing toxic effects and slowing growth (Vet et al., 2014). In addition 
Table 2. Anions amount $\left(\mathrm{kg} \mathrm{ha}^{-1}\right)$ in rainwater in an area inside São Gabriel municipality, Pampa biome.

\begin{tabular}{cccc} 
& $\mathbf{C l}^{-}$ & $\mathbf{N O}_{3}{ }^{-}$ & $\mathbf{S O}_{4}{ }^{2-}$ \\
\cline { 2 - 4 } Month & & $\mathbf{k g ~ h a}^{-1}$ & \\
\hline Mar & 0.18 & 0.10 & 0.08 \\
\hline Apr & 0.68 & 0.25 & 0.31 \\
\hline May & 0.73 & 0.16 & 0.50 \\
\hline Jun & 1.49 & 0.06 & 0.64 \\
\hline Jul & 0.45 & 0.14 & 0.74 \\
\hline Aug & 0.42 & 0.17 & 0.40 \\
\hline Sep & 0.45 & 0.15 & 0.75 \\
\hline Oct & 4.31 & 0.37 & 2.74 \\
\hline Nov & 1.14 & 0.74 & 2.35 \\
\hline Total & 0.48 & 0.18 & 0.51 \\
\hline
\end{tabular}

to effects through the soil, the chloride present in rainfall can corrode the surface of the leaves; therefore, in places with high concentrations of chloride in the atmosphere, the planting of trees is not considered an efficient mitigating measure to reduce the environmental impact caused by air pollution (Corvo et al., 2005).

Large amounts of $\mathrm{NO}_{3}, \mathrm{SO}_{4}^{2-}$, and $\mathrm{Cl}^{-}$in rainwater are a consequence of anthropogenic emissions, which contributed to the increase in air pollution (Armbruster et al., 2003); however, the vegetation burning are also responsible for the increased concentration of anions, such as sulfate, chloride, and nitrate, in the atmosphere, which modifies the chemical composition of the incident rainfall.

\section{CONCLUSION}

Vegetation burning influenced the chemical composition of the rainwater, which was acidic and presented increased concentrations of $\mathrm{Cl}^{-}$and $\mathrm{SO}_{4}^{2-}$. We recommend the use of other cultural practices of soil preparation that substitute the pasture and native grassland burning, aiming to reduce the emission of pollutants to the atmosphere. Despite the positive short-term effect of burning, the environmental consequences of rainwater quality are compromised, as acidification can hinder the development of agricultural crops and the quality of human and animal life.

\section{ACKNOWLEDGEMENTS}

The authors thank CMPC for the financial support and availability of the experimental area.

\section{SUBMISSION STATUS}

Received: 1 nov., 2018

Accepted: 5 apr., 2019

\section{CORRESPONDENCE TO}

\section{Grasiele Dick}

Universidade Federal de Santa Maria UFSM, Av. Roraima, 1000, Bairro Camobi, CEP 97105-900, Santa Maria, RS, Brasil

e-mail: grasidick@hotmail.com

\section{REFERENCES}

Alvares CA, Stape JL, Sentelhas PC, Moraes Gonçalves JL, Sparovek G. Köppen's climate classification map for Brazil. Meteorologische Zeitschrif 2014; 22(6): 711-728. http://dx.doi.org/10.1127/0941-2948/2013/0507.

American Public Health Association - APHA. American Water Works Association - AWWA. Water Environment Federation - WEF. Standard methods for the examination of water and wastewater. 19th ed. Washington: Water Pollution Control Federation; 1998.

Armbruster M, Abiy M, Feger K-H. The biogeochemistry of two forested catchments in the Black Forest and the eastern Ore Mountains (Germany). Biogeochemistry 2003; 65(3):341-368. http://dx.doi.org/10.1023/A:1026250209699.

Ashagrie Y, Zech W. Dynamics of dissolved nutrients in forest floor leachates: comparison of a natural forest ecosystem with monoculture of tree species plantations in south-east Ethiopia. Ecohydrology \& Hydrobiology 2010; 10(2-4): 183-190. http://dx.doi.org/10.2478/ v10104-011-0015-6.

Calil FN, Schumacher MV, Witschoreck R, Lopes VG, Viera $\mathrm{M}$, Liberalesso $\mathrm{E}$. Ion input via rainwater in southwestern region of Rio Grande do Sul, Brazil. Revista Ceres 2010; 16(3): 373-380.

Corvo F, Minotas J, Delgado J, Arroyave C. Changes in atmospheric corrosion rate caused by chloride ions depending on rain regime. Corrosion Science 2005; 47(4): 883-892. http://dx.doi.org/10.1016/j.corsci.2004.06.003.

Costa JA. O fenômeno El Niño e as secas no Nordeste do Brasil. Revista Científica do IFAL 2012; 1(4): 13-21.

Dick G, Schumacher MV, Momolli DR, Viera M. Nutrient input via incident rainfall in a Eucalyptus dunnii stand in the Pampa biome. Floresta e Ambiente 2018; 25(3): e20160559. http://dx.doi.org/10.1590/2179-8087.055916.

Duan L, Yu Q, Zhang Q, Wang Z, Pan Y, Larssen T et al. Acid deposition in Asia: emissions, deposition, and ecosystem effects. Atmospheric Environment 2016; 146: 55-69. http://dx.doi.org/10.1016/j.atmosenv.2016.07.018. 
Eisalou HK, Șengönül K, Gökbulak F, Serengil Y, Uygur B. Effects of forest canopy cover and floor on chemical quality of water in broad leaved and coniferous forests of Istanbul, Turkey. Forest Ecology and Management 2013; 289: 317-377. http://dx.doi.org/10.1016/j.foreco.2012.10.031.

Ferreira PMA, Setubal RB. Florística e fitossociologia de um campo natural no município de Santo Antônio da Patrulha, Rio Grande do Sul, Brasil. Brazilian Journal of Biosciences 2009; 7(2): 195-204.

Heartsill-Scalley T, Scatena FN, Estrada C, McDowell WH, Lugo AE. Disturbance and long-term patterns of rainfall and throughfall nutrient fluxes in a subtropical wet forest in Puerto Rico. Journal of Hydrology 2007; 333(2-4): 472-485. http://dx.doi.org/10.1016/j.jhydrol.2006.09.019.

Instituto Nacional de Meteorologia - INMET [online]. 2018 [cited 2018 Jan 12]. Available from: http://www. inmet.gov.br/portal/

Laclau J-P, Ranger J, Bouillet J-P, Dieu Nzila J, Deleporte P. Nutrient cycling in a clonal stand of Eucalyptus and an adjacent savanna ecosystem in Congo 3: Chemical composition of rainfall, throughfall and stemflow solutions. Forest Ecology and Management 2003; 176(1-3): 105-119. http://dx.doi.org/10.1016/S0378-1127(02)00280-3.

Mélo AS, Justino F, Lemos CF, Sediyama G, Ribeiro G. Suscetibilidade do ambiente a ocorrências de queimadas sob condições climáticas atuais e de futuro aquecimento global. Revista Brasileira de Meteorologia 2011;26(3): 401418. http://dx.doi.org/10.1590/S0102-77862011000300007.

Robertson SMC, Hornung M, Kennedy VH. Water chemistry of throughfall and soil water under four tree species at Gisburn, northwest England, before and after felling. Forest Ecology and Management 2000; 129(1-3): 101-117. http://dx.doi.org/10.1016/S0378-1127(99)00156-5.

Shen W, Ren H, Darrel Jenerette G, Hui D, Ren H. Atmospheric deposition and canopy exchange of anions and cations in two plantation forests under acid rain influence. Atmospheric Environment 2013; 64: 242-250. http://dx.doi.org/10.1016/j.atmosenv.2012.10.015.

Vet R, Artz RS, Carou S, Shaw M, Ro C-U, Aas W et al. A global assessment of precipitation chemistry and deposition of sulfur, nitrogen, sea salt, base cations, organic acids, acidity and $\mathrm{pH}$, and phosphorus. Atmospheric Environment 2014; 93: 3-100. http://dx.doi.org/10.1016/j. atmosenv.2013.10.060.

Wamelink GWW, Van Dobben HF, Mol-Dijkstra JP, Schouwenberg EPAG, Kros J, Vries W et al. Effect of nitrogen deposition reduction on biodiversity and carbon sequestration. Forest Ecology and Management 2009; 258(8): 1774-1779. http://dx.doi.org/10.1016/j.foreco.2008.10.024.

Wu D, Wang S, Xia J, Meng X, Shang K, Xie Y et al. The influence of dust events on precipitation acidity in China. Atmospheric Environment 2013; 79: 138-146. http://dx.doi. org/10.1016/j.atmosenv.2013.06.016. 